\title{
KKN SISDAMAS: OPTIMALISASI PEMBERDAYAAN MASYARAKAT MELALUI PENGGUNAAN SMARTPHONE UNTUK MARKETPLACE
}

\author{
(Sebuah Studi Kasus terhadap Warga Masyarakat Desa Cikoneng, Kecamatan Ganeas, Kabupaten \\ Sumedang, Jawa Barat, Indonesia)
}

\author{
Andang Saehu') ${ }^{1)}$ Fitriyani Nugraha ${ }^{2)}$ \\ 1) Sastra Inggris, Fakultas Adab dan Humaniora, UIN Sunan Gunung Djati, andangsaehu@uinsgd.ac.id \\ ${ }^{2}$ Pendidikan Bahasa Arab, Fakultas Tarbiyah dan Keguruan, UIN Sunan Gunung Djati, nugrahafitriyani19@gmail.com
}

\begin{abstract}
Abstrak
Belum ada penelitian yang komprehensif terkait pemberdayaan masyarakat menggunakan smart phone di Indonesia, khususnya di perkampungan di Jawa Barat. Menyikapi hal tersebut, penelitian ini bertujuan untuk meneliti bagaimana peserta KKN Sisdamas melaksanakan pemberdayaan masyarakat melalui penggunaan smarphone untuk pengembangan potensi Desa Cikoneng, Kecamatan Ganeas, Kabupaten Sumedang, Jawa Barat. Metode penelitian mengaini mengadopsi siklus-siklus KKN Sisdamas yang diajukan oleh Sururie, dkk. Data penelitian diperoleh melalui observasi terhadap 30 masyarakat yang menggunakan smartphone dalam keseharian mereka. Hasil penelitian menunjukkan bahwa melalui bantuan peserta KKN Sisdamas kelompok 139 berupa sosialisasi, pelatihan dan pembimbingan penggunaan smartphone, seluruh masyarakat yang terlibat dalam penelitian ini mampu menjual produk-produk mereka di lapak online atau marketplace. Terdapat enam kelompok usaha yang menjual produk merekamasingmasing di marketplace yang berbeda-beda. Beberapa menjual produk konveksi berupa kaos souvenir dari berbagai Negara, kunci, keranjang tahu, dan kerecek. Mereka cekatan dalam mengoperasikan berbagai aplikasi marketplace yang menunjang usaha mereka. Selain itu, merekapun telah mampu memanfaatkan berbagai macam fitur dan aplikasi yang terdapat dalam smartphone untuk menyerap dan berbagi informasi melalui internet browser engine dan youtube.
\end{abstract}

Kata Kunci: smartphone, pemberdayaan, optimalisasi, marketplace.

\begin{abstract}
Comprehensive studies on community empowerment using smart phone in Indonesia, especially in villages in West Java, are still limited. This research is to investigate how the students joining KKN Sisdamas implemented the program of community empowerpent through the use of smarphone for village development in Desa Cikoneng, Kecamatan Ganeas, Sumedang District, West Java. This research adopts the cycles of KKN Sisdaman proposed by Sururie, et al. The data were collected through observation to 30 people using smartphone as ther life screening. The result shows that under the KKN Sisdamas Group 139 are successful in socializing, training, and guiding the community to use their smartphone for trading in marketplaces. There are six groups of trading in different marketplaces that sell different products. Some of which sell T-Shirt souvenirs, kunci, keranjang tahu, and kerecek. The community can operate-sell their own products after having their own accounts in marketplaces. Besides, they also can use some features and applications existing in smartphone to get and share the information through internet browser engine and youtube.
\end{abstract}

Kata Kunci: smartphone, empowerment, optimalization, marketplace.

\section{PENDAHULUAN}

Gaung program Digitalisasi Desa yang dicanangkan oleh Ridwan Kamil, Gubernur Jabar sangat menggema sejak Beliau dilantik. Segera setelah itu, masih dalam 100 hari kerja banyak media masa melaporkan bahwa peluncuran Digital Desa diresmikan Gubernur Jawa Barat di Desa Puntang
Kecamatan Losarang, Indramayu pada tanggal 10 Desember 2018. Program digitalisasi desa bertujuan menyetarakan pola kehidupan berbasis digital masyarakat desa dan masyarakat kota.

Utopia desa digital tentu saja dimulai dari Situs Desa, penampilan papan elektronik pada tiap gerbang desa, running text pada papan selamat datang, fasilitas Drone, televisi, projector, 
smartphone, computer, dan sebagainya. Dengan digital desa, pada depan Kantor Kepala Desa tertayang berbagai info elektronik tentang profil Desa, seperti Peta Desa, jumlah penduduk, jumlah angka kelahiran dan kematian, dan lain-lain, rencana kegiatan bersama dan berbagai gawe, peraturan desa, tata tertib desa, kegiatan PKK, laporan panen harian dan lumbung desa, dan sebagainya. Semua itu gambaran dari Desa Digital yang dicanangkan Gubernur Jabar.

Merespon program Digital Desa, Rektor UIN Sunan Gunung Djati melalui unit LP2M menggagas kegiatan pengabdian pada 2019 dalam bentuk KKN Sisdamas. Sururi, ketua Pusat PkM UIN Bandung, menyebutkan bahwa terdapat 5203 mahasiswa UIN Sunan Gunung Djati Bandung yang berasal dari 48 Program Studi S1 bertempat di 127 Desa, dan 25 Kecamatan yang tersebar di Kabupaten Sumedang, Kabupaten Bandung, Kabupaten Pangandaran, Kota Banjar,Kabupaten Tasik, Kabupaten Cianjur, Kabupaten Bekasi, Negara Malaysia, dan Thailand mulai 29 Juli hingga 31 Agustus 2019.

Khusus untuk Kabupaten Sumedang mendapat porsi peserta KKN lebih banyak yaitu 3423 orang dengan konsiderasi agar program Digitalisasi Desa yang juga direspon baik oleh pemerintah daerah Sumedang dapat dijalankan dengan lebih optimal. Respon pemerintah Sumedang terhadap program Gubernur Jabar ini terlihat dalam sambutan Bapak Dony Ahmad Munir, Bupati Kabupaten Sumedang pada acara pembukaan dan serah terima peserta KKN Sisdamas di Kantor Pemerintahan Sumedang pada tanggal 01 Agustus 2018. Beliau mengatakan bahwa dalam upaya mensukseskan Sumedang yag Sejahtera, Agamis, Maju, Profesional, dan Kreatif (SIMPATI), kehadiran mahasiswa KKN dapat membawa pengaruh positif bagi daerah terutama dalam rangka mensukseskan digitalisasi 83 desa, 13 Kecamatan yang ada di Sumedang.

Fokus pada Desa Cikoneng Kecamatan Ganeas, para peserta KKN Sisidamas yang terbagi ke dalam tiga kelompok dan menempati tiga Rukun Warga melakukan Siklus 1 yaitu Rembug Warga dan Sosialisasi Warga untuk menjaring permasalahan dan potensi yang ada di masyarakat. Hasil dari Siklus 1 ini mencapai kesimpulan yang sama yaitu masyarakat usia sekolah dasar dan menengah mulai tergerus pengaruh media sosial yang berdampak pada menurunnya prestasi di sekolah; pada masyarakat usia dewasa (pemuda dan pemudi) ditemukan tingginya angka pengangguran meskipun memiliki potensi desa yang dapat dikembangkan yaitu desa wisata, desa kuliner, dan desa tani; sedangkan masyarakat usia lanjut masih belum mampu mengembangkan usaha produk rumahan, warung, konveksi, pertanian, perkebunan, dan peternakannya.

Mengetahui hal ini, peneliti selaku Dosen Pembimbing Lapangan dalam Siklus 2 duduk bersama peserta KKN Sisdamas dan masyarakat meliputi anak-anak, remaja, pemuda, tokoh masyarakat, tokoh agama, tokoh rukun warga, dan perwakilan aparat desa membahas rencana-rencana solusi yang akan dilakukan untuk mengentaskan permasalahan dan memberdayakan potensi desa yang ada. Salahsatu solusi yang diajukan dan menjadi fokus penelitian ini yaitu pemanfaatan smartphone dalam mengoptimalkan upaya pemberdayaan potensi-potensi masyarakat. Hal ini sejalan dengan ungkapan Praditya (2014) mengungkapkan bahwa perilaku masyarakat yang sudah terbiasa menggunakan smartphone jika digunakan untuk pengembangan desa merupakan bagian kecil dari digital desa.

Selama ini ICT (teknologi informasi dan komunikasi) bergerak dan berkontribusi banyak dalam bidang pendidikan, terutama dalam proses belajar mengajar (Kee \& Samsudin, 2015; Khaloufi, Az-eddine, \& Laabidi, 2017). Padahal smartphone yang merupakan bagian dari ICT bergerak maju hingga ke berbagai dunia, seperti dunia kerja, dunia produksi dan industri, dan dunia keagamaan. Hal ini tidak menutup kemungkinan, warga yang tinggal di pedesaanpun sudah dominan mengenal smartphone. Idris (2018) mengungkapkan bahwa Indonesia adalah negara pengguna sosial media terbesar di Asia tenggara yang mencapai hingga 79 juta pengguna aktif. 16,4 juta dari 79 juta pengguna aktif media sosial adalah warga Jawa Barat (Kemenko PMK, 2019).

Untuk mendapatkan manfaat dari adanya smartphone, peneliti melibatkan peserta KKN Sisdamas agar dapat terlibat setahap lebih dekat dengan warga Desa Cikoneng, Sumedang. Smartphone dan warga saat ini dapat dikatakan memiiki hubungan yang sangat 'erat.' Upaya ini sejalan dengan ungkapan Prensky (2001) bahwa smartphone saat ini telah menjadi 'life screening' atau 'teman hidup' bagi masyarakat remaja dan pemuda (digital natives) serta masyarakat lainnya. Penggunaan smartphone semakin hari kian meningkat, namun hanya sedikit yang dapat memanfaatkan keuntungan dari kepemilikan smartphone baik untuk belajar maupun untuk menjadi sumber informasi yang dapat mengembangkan potensi diri pengguna.

Penelitian terkait penggunaan atau pemanfaatan smartphone didominasi oleh mereka yang fokus terhadap dunia pendidikan. Misalnya, penelitian oleh Yudhiantara \& Saehu (2017) yang fokus pada 
penggunaan mobile phone untuk mempelajari bahasa Inggris melalui aplikasi English Monolingual Dictionary. Peneliti lainnya yaitu Zeng \& Luyegu (2011) juga fokus pada penggunaan mobile phone di kalangan mahasiswa yang duduk di bangku universitas. Sampai sejauh ini, penelitian berbasis teknologi terhadap desa-desa lebih fokus pada teknologi informasi dan komunikasi (TIK). Penelitian oleh Ridwan, Hakim, \& Firmansyah (2018) menunjukkan bahwa kesiapan pihak Desa baik aparat desa (SDM), sarana prasarana, dan anggaran terhadap penerapan TIK dalam rangka menertibkan administrasi desa masih menjadi kendala. Hasil penelitian mereka juga menemukan bahwa penerapan TIK belum merata di seluruh desa.

Dalam konteks pendidikan, penggunaan mobile phone sudah mendapat perhatian yang cukup dan memberikan kontribusi yang besar bagi pengembangan pendidikan. Penelitian ini memiliki harapan yang sama bahwa smartphone dapat memberikan impact dan manfaat bagi pengguna yang berada di Desa Cikoneng, Kec. Ganeas, Sumedang, Jabar. Penelitian ini berupaya mengisi kesenjangan penelitian terkait penggunaan smartphone dalam dunia kemasyarakatan. Secara spesifik, penelitian ini fokus pada bagaimana peserta KKN Sisdamas, khususnya Kelompok 139, melaksanakan pemberdayaan masyarakat melalui penggunaan smarphone untuk pengembangan potensi Desa Cikoneng, Sumedang, Jawa Barat.

\section{TEORI}

Secara umum bagian ini membahas tentang smarphone dan manfaatnya. Smartphone hadir di negara kita, Indonesia dengan berbagai fitur dan kemanfaatannya. Sebelumnya, sebuah penelitian yang dilakukan di Korea menunjukkan bahwa smartphone adalah ubiquitous learning. Setiap orang dapat belajar dan memanfaatkan smartphone kapanpun dan dimanapun. Di sekolah, smartphone dapat digunakan untuk mengakses bahan pembelajaran. Di perkantoran, smartphone dapat digunakan untuk presentasi projek. Di pemerintahan, smartphone dapat digunakan untuk menyebarkan informasi bebas hoax melalui aplikasi sosial media. Di masyarakat, smartphone dapat digunakan untuk mengembangkan home industry dan transaksi lainnya.

Fitur-fitur yang terdapat dalam smartphone dapat dimanfaatkan dengan baik oleh siapapun. Sebagi contoh keberadaan kamera dalam smartphone. Bull (2004) menemukan bahwa kamera dapat membantu proses pembelajaran. Sebagaimana diketahui, proses pembelajaran bersifat umum tergantung siapa yang hendak memanfaatkan fitur tersebut. Jika seseorang adalah mahasiswa photography, kamera dapat dijadikan alat untuk menangkap benda yang diinginkan agar dapat dianalisis dari segi ilmu pfotograpi. Jika ia adalah seorang pelajar, kamera dapat digunakan untuk menangkap slide powerpoint untuk kemudian dipelajari lebih lanjut setelahnya. Jika dia adalah seorang pengusaha, maka kamera dapat dijadikan alat untuk memotret produk-produknya agar dapat dipromosikan ke pada khalayak luas melalui marketplace.

Fitur lainnya yaitu audio video yang terbukti efisien bagi sebagian orang dalam melakukan transaksi jual beli. Barang yang dijualnyapun terasa lebih menarik dengan adanya motion picture. Terkait hal ini, Smythe (2010) mengungkap bahwa audio video telah banyak dimanfaatkan oleh para mahasiswa dalam mebuat podcast yang berhubungan dengan materi yang sedang dipelajari. Hal ini tidak menutup kemungkinan, para pegiat bisnis dapat memanfaatkan fitur tersebut dengan lebih hidup untuk memikat minat para konsumen. Aplikasi youtube misalnya seringkali menjadi tempat ekspressif untuk mengunggah konten yang sudah disiapkan dari fitur audio video. Bahkan, tidak sedikit banyak orang yang meraup keuntungan dari aplikasi tersebut dengan mengundang orang untuk subscribe, like, comment dan share.

Fitur yang tidak kalah menarik dari smartphone yaitu internet search engine. Penelitian yang dilakukan oleh Rogers, Weltevrede, Niederer, \& Borra (2012) di Iran menemukan bahwa keberadaan fitur internet search terbukti lebih memberikan manfaat yang positif bagi para mahasiswa dalam memahami konsep dan instruksi, mampu berfikir kritis, dan meningkatkan kreatifitas dalam belajar. Jika hasil penelitian ini diekstrak terhadap masyarakat yang ada di pedesaan dengan melibatkan para mahasiswa yang sudah terbiasa dengan internet search engine, manfaatnya tentu tidak akan terbatas pada dunia pendidikan melainkan dunia masyarakat pedesaan, seperti dunia pertanian, dunia peternakan, dunia perkebunan, dunia home industry, dan dunia-dunia lainnya. Melalui mesin pencarian internet, mereka dapat melihat atau mengadospi cara orang-orang sukses melakukan pertanian, peternakan, perkebunan, dan sebagainya.

Selain kehebatan-kehebatan fitur yang ada dalam smartphone, aplikasi-aplikasi yang dapat dengan mudah diunduh melalui playstore atau AppStore, juga memberikan manfaat yang besar bagi pengguna aktif. Aplikasi-aplikasi tersebut diunduh sesuai dengan kebutuhan perorangan atau 
perkelompok, seperti aplikasi WhasApp, Facebook, Instagram, google drive, duolingo, kamus, bukalapak, shopee, tokopedia, cam scanner dan sebagainya. Orang yang satu dengan orang yang lainnya dapat berinteraksi baik secara audio (audio call) maupun video (video call). Markett (2006) mempelajari hubungan antara dua orang yang berbeda dalam sebuah seting kegiatan. Menurutnya, interaksi yang di dalamnya terdapat emosi (perasaan dan ekspresi) dapat juga tercipta melalui aplikasi yang ada dalam smartphone. Bahkan seseorang dapat mengirim pesan teks, pesan suara, tugas, dan projek melalui aplikasi yang ada dalam smartphone, sebagai contoh WhatsApp. Pegrum, Oakley, \& Faulker (2013) menyebutkan bahwa banyak orang dapat melakukan banyak hal, seperti kegiatan belajar di dalam kelas, dengan menggunakan smartphone.

\section{METODOLOGI PENGABDIAN}

Metode pengabdian kepada masyarakat yang dilakukan mengadopsi langkah-langkah pengabdian berbasis pemberdayaan masyarakat (Sisdamas) yang diusung oleh Tim Pusat Pengabdian LP2M UIN Sunan Gunung Djati Bandung, yaitu Siklus I hingga IV. Para peserta KKN bersama DPL memulainya dengan melakukan observasi lapangan (tansec) untuk melihat secara sekilas potensi dan permasalahan yang ada di Desa Cikoneng. Potensi dan permasalahan juga digali melalui wawancara dengan Kepala Desa dan lima Warga. Wawancara mendalam dan intens terhadap mereka kemudian dilakukan pada saat KKN Sisdamas berlangsung.

Data juga dikumpulkan tidak hanya melalui wawancara tetapi juga melalui obervasi partisipatif saat pelaksanaan KKN Sisdamas berlangsung. Para peserta KKN dengan aktif mensosialiasikan system pemasaran yang relative gratis karena hanya memerlukan kemauan dan keberanian untuk bersaing di tingkat global melalui maraketplace. Metode berikutnya lebih fokus pada pelatihan dan pembimbingan pemanfaatan smartphone kepada warga-warga di Desa Cikoneng, terutama kepada mereka yang memiliki hasrat tinggi untuk maju dan berkembang.

Selanjutnya metode deskriptif diterapkan untuk menganalisis data yang diperoleh melalui observasi dan wawancara dengan cara menjelaskan, mengkategorikan, dan menginterpretasikan data.
Trianggulasi dilakukan dalam penelitian ini untuk meningkatkan tingkat validitas hasil penelitian.

\section{PELAKSANAAN KEGIATAN}

Penelitian ini berupaya mengungkap kebiasaan masyarakat Desa Cikoneng Kecamatan Ganeas Kabupaten Sumedang dalam menggunakan smartphone dan upaya para peserta KKN Sisdamas dalam melaksanakan program pemberdayaan masyarakat dengan memanfaatkan smartphone untuk mengembangkan potensi-potensi yang ada pada masyarakat. Analisis dilakukan secara integratif yaitu data tentang kebiasaan masyarakat dalam menggunakan smartphone digabungkan dengan data tentang upaya atau prosedur pemberdayaan masyarakat.

\section{HASIL DAN PEMBAHASAN}

Prosedur Pemberdayaan Masyarakat Melalui Penggunaan Smartphone untuk Mengembangkan Potensi Masyarakat Desa Cikoneng, Kecamatan Ganeas, Sumedang

Para peserta KKN Sisdamas UIN Sunan Gunung Djati Bandung yang mendapat tugas untuk melaksanakan program pengabdian dan pemberdayaan pada masyaraka di Desa Cikoneng, Sumedang berjumlah 39 orang dari berbagai program studi. Mereka dibagi menjadi 3 kelompok, yaitu kelompok 139 dengan jumlah 13 orang berlokasi di RW 02, kelompok 140 dengan jumlah 13 orang menempati lokasi RW 04, dan kelompok 141 dengan jumlah yang sama bertugas di RW 05 . Tiap-tiap kelompok diketuai oleh satu orang yang disebut sebagai KKP. Dari seluruh kelompok, dipilih satu orang untuk menjadi Koordinator Desa (Kordes) yang tugasnya menjalin komunikasi dengan aparat desa. Semua kelompok menjalankan prosedur pelaksanaan KKN Sisdamas yang sama di masing-masing tempat, yaitu Siklus I, Siklus II, Siklus III, dan Siklus IV sebagaimana diamanahkan oleh pihak Pusat Pengabdian LP2M UIN Sunan Gunung Djati dalam buku pedoman KKN Sisdamas 2019, bahwa:

"Guna mewujudkan keberhasilan pemberdayaan masyarakat dalam kegiatan $\mathrm{KKN}$, diperlukan berbagai langkah atau metode pemberdayaan. Siklus pemberdayaan masyarakat merupakan 
tahapan yang penting dilalui oleh mahasiswa dan dosen pembimbing lapangan (DPL) yaitu penelusuran wilayah, sosialisasi awal dan rembug warga, refleksi sosial, pemetaan sosial, pengorganisasian masyarakat, perencanaan partisipatif, sinergi program, pelaksanaan program, dan monitoring evaluasi."

Keseluruhan rangkaian langkah-langkah pelaksanaan KKN di atas harus dilalui oleh peserta dan DPL dalam waktu 30 hari. Oleh karena itu DPL selaku peneliti bersama dengan peserta bersinergi dengan berbagai pihak agar tujuan KKN Sisdamas tercapai. Berikut adalah rangkaian langkah-langkah atau prosedur yang dilakukan.

\section{Siklus I: Sosialisasi Awal, Rembug Warga dan Refleksi Sosial}

Dari satu bulan waktu yang disediakan oleh LP2M UIN Bandung untuk mejalankan KKN Sisdamas, DPL dan peserta KKN memanfaatkan waktu tersebut dengan matang. Minggu pertama, Siklus I dilakukan di masing-masing RW oleh kelompok masing-masing. Tujuan utama yang ingin dicapai dalam Siklus I yaitu terjalinnya hubungan yang baik dengan masyarakat, teridentifikasinya kelompokkelompok masyarakat, mengetahui klasifikasi masyarakat, mengetahui berbagai masalah yang ada di masyarakat, membangun kesadaran atas akar permasalahan yang ada di masyarakat, dan mengiventarisir harapan-harapan masyarakat dan pemerintah setempat.

Sebelum melakukan Siklus I, peneliti pada tanggal 01 Agustus 2019 mengumpulkan seluruh kelompok di Posko 139 untuk memberikan pengarahan tentang hal-hal yang harus disiapkan dalam Siklus I. Arahan juga diberikan dalam bentuk tayangan-tayangan video yang menunjukkan caracara peserta KKN Sisdamas tahun-tahun sebelumnya melakukan Siklus I. Berbagai ide kreatif muncul dari peserta setelah diberikan arahanarahan untuk melakukan Siklus I. Setelah salah satu ide kreatif diputuskan, seluruh peserta melakukan simulasi Siklus I agar pada pelaksanaannya berjalan lancar.

Peneliti juga mengarahkan Kordes untuk melaporkan rencana pelaksanaan Siklus I sekaligus meminta arahan dari Kepala Desa terkait pihakpihak yang harus diundang untuk menghadiri Siklus I. Surat undangan dengan diketahui oleh Kepala Desa disebar kepada masyarakat yang terdiri dari Tokoh Agama (Toga), Tokoh Masyarakat (Tomas), Tokoh Pemuda (Toda), komunitas petani, buruh tani dan bangunan, peternak, seni, pengrajin, dan konveksi.

Pelaksanaan Siklus I diselenggarakan sesuai dengan karakteristik masing-masing RW atas arahan Kades Cikoneng. Sehingga masing-masing kelompok KKN melaksanakan Siklus pada hari yang berbeda. Kelompok 139 melakukan Siklus I pada tanggal 5 Agustus 2019 bertempat di Aula Desa Cikoneng pukul 16.00 - 17.15. Kelompok 140 dan 141 melakukan Siklus 1 secara berurutan pada tanggal 6 dan 7 Agustus pada malam hari di Mesjid dan Posko 141. Satu hal yang sama yaitu mereka melakukan cara yang sama sesuai simulasi Siklus I.

Pada saat pelaksanaan Siklus I, KKP memperkenalkan diri dan anggota kelompoknya. Silaturahim dijadikan kata kunci pada pertemuan tersebut dibubuhi hadis yang mendukungnya bahwa "Barangsiapa yang beriman kepada Allah dan Rasulnya, segeralah lakukan silaturahim." Kata kunci ini tampaknya menyentuh hati dan memikat perhatian para tamu undangan. Pada saat yang sama, KKP menggunakan momen tersebut dengan mengutarakan tujuan pertemuan pada Siklus I dengan cara yang kreatif. Sejurus kemudian, seluruh peserta Kelompok membagikan kertas kosong beserta alat tulis kepada masyarakat. KKP kemudian menginstruksikan:

"Bapak/Ibu yang terhormat, dimohon kiranya untuk mengisi Nama dan Jenis Pekerjaan saat ini. Setelah selesai mengisi identitas, kami ada beberapa pertanyaan secara lisan, mohon dijawab dengan cara menulis di kertas yang sudah diisi."

Para tamu undangan merespon instruksi tersebut penuh antusias pada kertas warna warni. Bahkan mereka langsung menjawab beberapa pertanyaan yang diajukan, diantaranya "Selain pekerjaan utama tersebut, pekerjaan sampingan apa yang Bapak/Ibu lakukan?" "Masalah atau kendala apa yang Bapak/Ibu hadapi terkait pekerjaan tersebut?" "Apa penyebab masalah-masalah tersebut?" 
Merekapun menyerahkan kembali kertas yang sudah diisi tersebut kepada peserta KKN.

Peserta KKN kemudian menuliskan jawaban mereka di Papan Tulis dengan kategori Pekerjaan, Masalah dan Solusi. Menurut hasil isian masyarakat, terdapat tiga kategori pekerjaan: Home Industry, pertanian, konveksi, dan perkebunan. Permasalahan utama yang muncul yaitu sulitnya memasarkan produk rumahan, produk hasil panen, hasil kebun, dan produk ternak. Permasalahan lain yang juga mencuat yaitu pengangguran, kenakan remaja, sampah dan MCK.

Siklus I dengan tujuan menggali potensi dan permasalahan masyarakat Desa Cikoneng berhasil dilaksanakan dengan baik. Beberapa potensi dan masalah sudah dapat diidentifikasi. Para peserta KKN sangat berterimakasih kepada masyarakat yang sudah membantu kelancaran pelaksanaan Siklus I dan mereka bersedia hadir kembali pada Siklus II untuk bersama-sama mencari solusi terbaik atas masalah mereka.

\section{Siklus II: Pemetaan Sosial dan Pengorganisasian Masyarakat}

Siklus ini sering juga dikenal dengan istilah Tagamas (Pemetaan Sosial dan Pengorganisasian Masyarakat). Fridayanti, dkk (2019) mengungkapkan bahwa pemetaan sosial ini bertujuan untuk memetakan kebutuhan, potensi dan masalah secara mandiri oleh masyarakat sendiri. Setelah terpetakan, mereka difasilitasi oleh peserta KKN untuk mengoptimalkan organisasi kemasyarakatan yang ada atau membentuk organisasi masyarakat warga dalam bentuk perkumpulan atau paguyuban berdasarkan kebutuhan, masalah dan aset yang muncul dari pemetaan sosial.

Dengan fokus pada salah satu kelompok KKN yaitu 139 karena kelompok inilah yang kemudian memberdayakan pemanfaatan smartphone kepada warga, pelaksanaan Siklus II terjadi pada minggu kedua tanggal 12 Agustus 2019. Atas kerjasama Kordes dengan Aparat Desa, masyarakat kembali hadir pada pertemuan Siklus II untuk menindaklanjuti hasil Siklus I. KKP 139 menyampaikan kembali masalah dan potensi yang diidentifikasi pada Siklus I untuk merecall ingatan masyarakat. Kemudian KKP menyampaikan tujuan pertemuan pada Siklus II.

"Para Bapak/Ibu, Siklus II ini digelar dengan tujuan untuk memetakan permasalahan yang perlu diprioritaskan agar memberi dampak yang optimal kepada warga di sini. Sekaligus akan membentuk satu organisasi masyarakat yang relevan dengan permasalahan"

Merujuk pada Netting, Kettner dan McMurtry (1993), pemetaan sosial dapat disebut juga sebagai social profiling atau "pembuatan profile suatu masyarakat". Pemetaan sosial dapat dipandang sebagai salah satu pendekatan dalam Pengembangan Masyarakat yang oleh Twelvetrees (1991:1) didefinisikan sebagai "the process of assisting ordinary people to improve their own communities by undertaking collective actions." Sebagai sebuah pendekatan, pemetaan sosial sangat dipengaruhi oleh ilmu penelitian social

Seluruh anggota kelompok memainkan perannya masing-masing untuk kesuksesan Siklus II. Acara dipandu oleh seorang pemandu diskusi agar terjadi interaksi antara masyarakat yang satu dengan lainnya serta berbagi pengalaman. Sebagian anggota lainnya mendampingi masyarakat sambil memerhatikan prosesi Siklus II dengan tujuan agar peserta yang tampak pasif menjadi aktif. Sebagian lainnya mencatat proses berlangsungnya Tagamas sebagai dokumentasi dan kemudahan pemetaan kebutuhan sosial. Sedangkan sebagian lainnya berperan sebagai fotographer yang mendokumentasikan kegiatan Siklus II.

Jika melihat teori yang diajukan oleh Warren (1978) dalam The Community in Amerika yang kemudian dikembangkan oleh Neting, Kettner, dan McMurty (1993:68-92) terdapat empat fokus dan sembilan tugas, namun dalam Siklus II ini pemetaan difokuskan pada masalah atau potensi yang sedang dihadapi oleh masyarakat. Adapun variabel-variable lainnya seperti jumlah populasi, batas wilayah geografis, nilai-nilai budaya atau tradisi, dan organisasi keagamaan (perbedaan pandangan) diperoleh melalui cara lain yang langsung berhubungan dengan pihak aparat desa.

Fokus pemetaan sosial yang dilakukan bersumber pada Siklus I yaitu terdapatnya masalah atau potensi home industry, konveksi, pertanian, 
perkebunan, pengangguran, kenakan remaja, sampah, dan MCK. Dari Siklus I inilah, pemetaan sosial difokuskan pada variabel pengidentifikasian struktur. Variabel tersebut erat kaitannya dengan sumber dana atau modal — apa dan siapa yang peduli terhadap masyarakat dalam bentuk bantuan suntikan dana untuk mengembangkan potensi mayarakat. Ada dua langkah yang dilakukan saat Siklus II untuk memetakan kebutuhan sosial berbasis identifikasi struktur yaitu membuat pohon masalah dan wawancara.

Wawancara dilakukan kepada masyarakat yang hadir "Menurut Ibu atau Bapak, apa yang menyebabkan kemiskinan?" mayoritas yang hadir menjawab "Banyak pengangguran," lalu "Apa yang kmenyebabkan Kenakalan Remaja?" mayoritas pun menjawab "Banyak yang gak kerja dan kurang pendidikan agamanya." Katakunci dari penyebab kemiskinan dan kenakalan remaja yaitu pengangguran. Wawancara dilanjutkan dengan pertanyaan "Bapak dan Ibu, kenapa banyak pengangguran?" Secara dominan jawaban mereka mengarah pada kata lapangan kerja minim, pendidikan rendah baik pendidikan formal maupun non-formal (agama).

KKP melanjutkan pembicaraannya "Pada pertemuan sebelumnya, kami mengidentifikasi potensi-potensi di Desa. Apa masalahnya potensi tersebut tidak dapat menekan tingkat kemiskinan dan kenakalan remaja di sini?" hasil wawancara menunjukkan bahwa penyebab utamanya adalah minim modal atau dana. Setelah permasalahan sosial terpetakan, para peserta KKN membentuk perkumpulan atau komunitas pemberdayaan. Tugas utama dari komunitas yang terbentuk ini yaitu untuk menjadi Duta bantuan sosial yang memfasilitasi pemecahan masalah dan pengembangan potensi yang ada.

Setelah komunitas pemberdayaan atau Duta bantuan sosial terbentuk, dibawah arahan peserta KKN mereka pada siklus berikutnya dibina caracara membuat proposal pengajuan dana yang baik untuk diajukan kepada instansi-instansi terkait. Proposal pengajuan dana lebih ditekankan pada bantuan modal dan pengembangan potensi agar terbuka lapangan kerja dari home idustry, pertanian, peternakan, dan konveksi.

\section{Siklus III: Perencanaan Partisipatif dan Sinergi Program}

Siklus ketiga dilaksanakan oleh Kelompok 139 pada minggu ketiga yaitu tanggal 21 Agustus 2019. Siklus ini merupakan kelanjutan dari Siklus II. Dengan kata lain, kegiatan yang ada dalam Siklus II dianggap belum selesai. Tidak cukup hanya sampai memetakan kebutuhan masyarakat dan membentuk komunitas pemberdayaan, namun perlu menyusun rencana program partisipatif dan mensinergikan program partisipatif tersebut (Resinpro).

Komunitas Pemberdayaan yang sudah terbentuk pada Siklus II memainkan perannya pada Siklus III ini. Mereka mulai menyusun dokumen perencanaan partisipatif (dorantif) dengan merujuk pada pemetaan sosial. Dalam Dorantif ini sudah ditentukan prioritas program yang harus disinergikan dengan berbagai instansi pemerintahan terkait. Program prioritas tersebut yaitu mengentaskan kemiskinan dan kenakalan remaja dengan menekan angka pengangguran melalui modal usaha agar tercipta lowongan kerja sesuai bidang potensi yang ada di masyarakat.

Masyarakat kembali diundang oleh peserta KKN untuk menjalankan Siklus III pada tanggal 23 Agustus 2019 di Mesjid ba'da Isya hingga selesai. Kali ini pertemuan lebih didominasi oleh laporan Komunitas Pemberdayaan terhadap masyarakat tentang rencana kerja prioritas yang akan dilakukan. Mereka mengungkapkan bahwa untuk memperoleh bantuan dana atau modal kerja, proposal akan dibuat di bawah arahan para peserta KKN dan akan diajukan ke Dinas Perindustrian dan Perdagangan, Dinas Pertanian, dan Dinas-Dinas lainnya.

Akan tetapi, salah seorang tokoh masyarakat memberikan pendapat bahwa

"Jadikan saja rencana tersebut sebagai rencana jangka panjang. Tolong diputuskan rencana jangka pendek pada pertemuan ini."

Baik peserta KKN, Komunitas Pemberdayaan, dan masyarakat yang hadir kemudian membahas rencana jangka pendek. Terkait hal ini, Ife (1995:71) menyebutkan bahwa "one could be that of decison making in a short time." Peserta KKN kembali menegaskan bahwa seandainya modal usaha terkumpul, marketing atau pemasaran akan menjadi momok dalam dunia bisnis. Selanjutnya KKP mengatakan: 
“Tampaknya yang perlu ditekankan pada saat ini yaitu bentuk pemasaran yang zaman now dengan memanfaatkan smartphone Bapak dan Ibu."

Masyarakat menyambut baik tentang ide pemasaran tersebut. Ketua Komunitas Pemberdayaan dengan sigap memberi saran:

"Kalau demikian, kita susun jangka pendek ini mulai dari pelatihan dan pembimbingan oleh pihak mahasiswa terkait cara-cara menggunakan smartphone untuk pengembagan potensi Desa kita."

Dari penggalan-penggalan percakapan pada Siklus III di atas, dapat disimpulkan bahwa pada Siklus Resinpro telah menghasilkan Dorantif dengan prioritas jangka panjang dan jangka pendek. Jangka panjang berupa penyusunan proposal modal usaha yang disinergikan dengan dinas-dinas pemerintahan terkait. Sedangkan jangka pendek akan dilakukan dalam bentuk pelatihan dan pembinaan penggunaan smartphone untuk pengembangan potensi desa terutama pemasaran produk pertanian, peternakan, home industri, dan konveksi.

\section{Siklus IV: Pelaksanaan Program dan Monitoring Evaluasi}

Siklus terakhir dikenal juga dengan istilah Lakmonev yaitu pelaksanaan program dan monitoring evaluasi. Program-program prioritas yang sudah disepakati pada Siklus Resinpro, mulai dilaksanakan pada minggu ke empat dalam bentuk pelatihan dan pembimbingan. Tujuan utama dari Siklus Lakmonev ini adalah melaksanakan program hasil prioritas perencanaan partisipatif, membentuk kelompok kerja atau panitia dengan prinsip dari, oleh, dan untuk masyarakat, memobilisasi peran masyarakat dalam melaksanakan program, dan membangun kesadaran masyarakat dalam partisipasi pelaksanaan kegiatan hingga monitoring dan evaluasi.

Proses pelaksanaan Siklus IV dilakukan di Balai Desa pada minggu keempat tanggal 27 Agustus 2019 oleh seluruh kelompok peserta KKN Sisdamas dan Komunitas Pemberdayaan selaku Orgamas yang dibentuk pada Siklus Tagamas. Jika pada Siklus sebelumnya, pihak peserta KKN mengundang masyarakat untuk hadir di setiap pertemuan Siklus.
Pada Siklus terakhir ini Orgamas mengundang dan memfasilitasi warga untuk melaksanakan program sesuai Dorantif. Para peserta KKN difungsikan sebagai relawan trainer yang akan melatih dan membimbing masyarakat menggunakan smartphone untuk pemasaran produk.

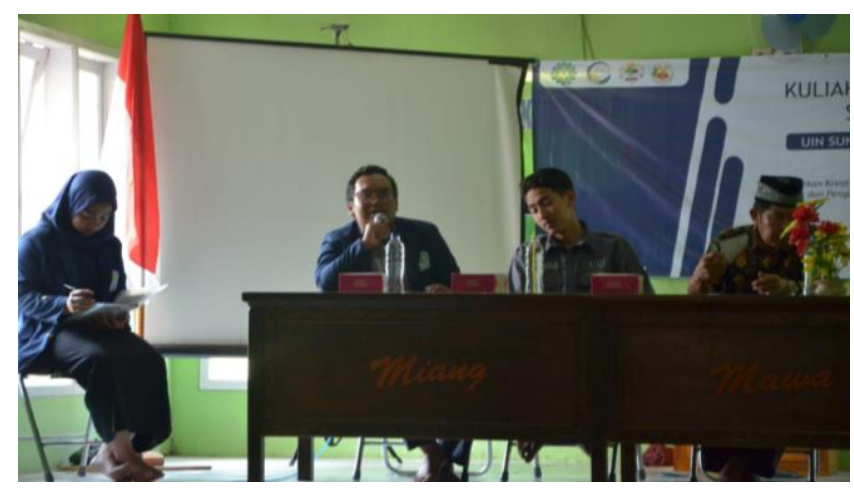

Gambar 1. Pelatihan Smartphone for Marketplace

Gambar 1 menunjukkan KKP 139 sedang berperan menjadi trainer pelatihan smartphone didampingi oleh Komunitas Pemberdayaan. Pada pelatihan ini, para tamu undangan dikumpulkan dalam satu ruangan besar di Balai Desa Cikoneng untuk mengikuti pelatihan smartphone for trading in Marketplace. Mereka dibagi kelompok sesuai jenis usaha atau pekerjaannya dan setiap kelompok didampingi oleh mahasiswa. Terdapat tiga kelompok, yaitu kelompok petani dengan produk hasil tani, kelompok home industri dengan produk keranjang tahu, kerecek, kunci dan kareo, dan kelompok konveksi dengan produk kaos, kemeja, kerudung, dan celana.

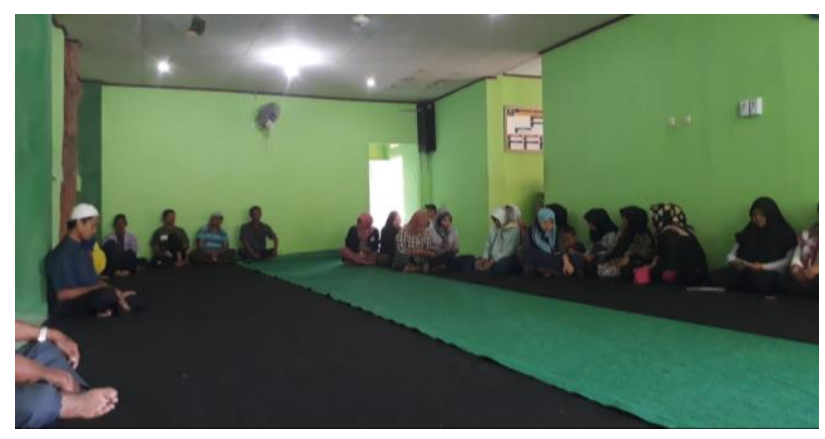

Gambar 2. Peserta Pelatihan Smartphone for Marketplace

Masyarakat diberi informasi tentang urgensi bisnis berbasis online, dasar-dasar bisnis online, dan etika berbisnis online. Mereka juga diberi materi 
tentang cara-cara memasarkan produk secara online, mulai dari pembuatan akun e-mail, pedaftaran lokasi usaha, dan pendaftaran akun di marketplace. Hampir tidak ada kendala yang berarti karena setiap orang didampingi oleh mahasiswa yang sigap membantu proses jualan online dari awal hingga mendapati tokonya bertengger di marketplace. Siapapun berkesempatan membuka tokonya secara online untuk produk apapun selama produk tersebut tidak bertentangan dengan ketentuan hukum, seperti produk minuman keras, ganja, sabu, dan sejenisnya. Tercatat ada enam toko yang terdaftar di marketplace dengan produk yang beragam. Bu Siti Saadiyah membuka toko di Bukalapak dengan produk bahan jamu yang disebut kunci. Pak Rohman juga membuka lapaknya di marketplace yang sama dengan Bu Siti Saadiyah dengan menjual hasil jahitannya berupa kaos. Ada anak remaja bernama Susi yang menjual Kerecek Cikoneng di lapak yang berbeda dengan pelapak lainnya, yaitu Tokopedia. Begitupun Ibu-Ibu dan Bapak-Bapak yang lainnya melakukan hal yang sama dengan produk yang beragam. Berikut ini adalah beberapa lapak jualan online di marketplace hasil pembinaan peserta KKN Sisdamas UIN Sunan Gunung Djati Bandung (lihat Gambar 3 dan 4).

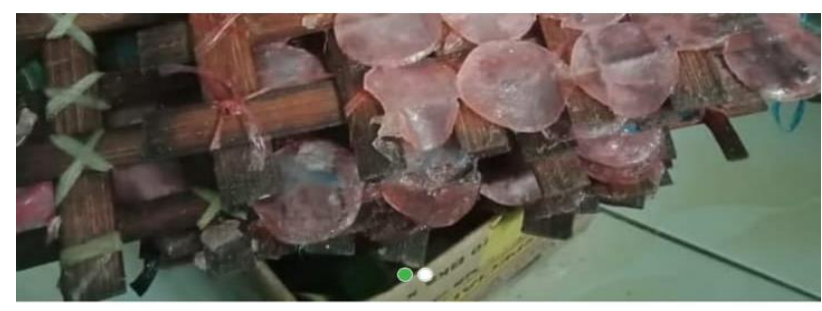

\section{Kerecek Cikoneng}

\section{Rp15.000}

Stok terbatas! Tersedia $>50$

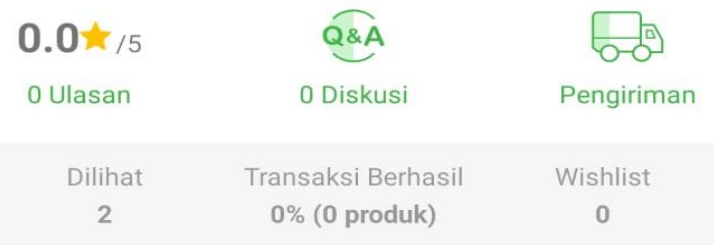

Ongkos Kirim mulai dari Rp8.000

맘 dari Kab. Sumedang

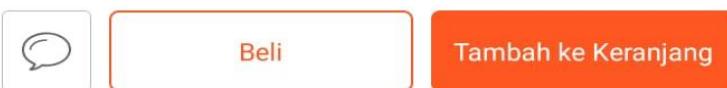

Gambar 3. Lapak Home Industry di Marketplace

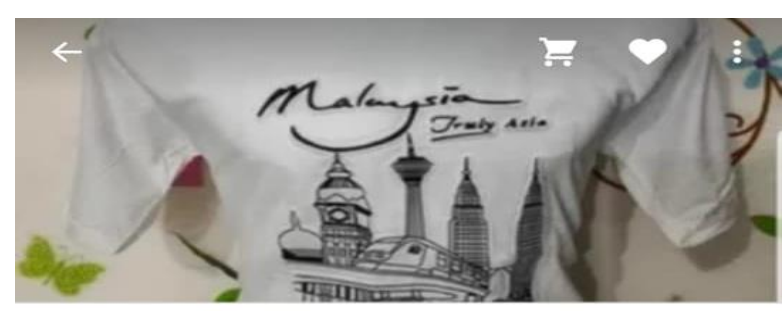

Kaos Souvenir Luar Negeri

Rp17.500

Nego

Informasi Barang

Stok

Kami konveksi asal cikoneng memproduksi kaos soucenir dari berbagai negara sesuai pesanan. Tersedia ukuran S, M, L, XL, XXL

warna yang ready: Putih, Biru, Orange, Abu.

$$
\text { Selengkapnya }
$$

Pelapak

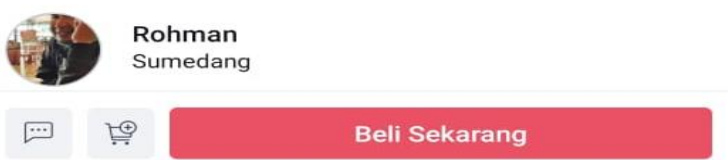

Gambar 4. Lapak Konveksi di Marketplace 
Terkait rencana jangka panjang, Komunitas Pemberdayaan terus melakukan koordinasi sekaligus meminta arahan pihak Desa terkait prosedur pengajuan modal usaha menggunakan proposal kepada dinas-dinas pemerintahan terkait. Salahsatu lembaga pemerintah yang menyediakan bantuan dana bagi para UKM adalah Koperasi dan UKM Deputi Bidang Pembiayaan. Keberadaan mereka adalah untuk membantu perekonomian rakyat. Dengan mengetahui prosedur pengajuan dana, masyarakat akan lebih menyiapkan diri untuk mengikuti aturan-aturan yang ada. Mahasiswa dalam hal ini telah berupaya mengantarkan masyarakat Desa Cikoneng Sumedang ke jenjang yang lebih kritis terhadap dunia usaha.

Penelitian ini telah mengungkap bahwa mayoritas masyarakat Desa Cikoneng, Sumedang Jawa Barat meiliki smartphone yang seringkali digunakan untuk mengakses sosial media, namun mereka belum bisa memaksimalkan penggunaannya. Hal ini sejalan dengan penelitian Lenhart (2015) bahwa terdapat kecenderungan para pengguna smartphone untuk kesenangan mereka. Beberapa aplikasi yang sebelumnya diunduh untuk keperluan media sosial, saat ini bertambah dengan aplikasi marketplace sebagai sarana untuk membuka lapak jualan mereka.

Berdasarkan fakta di lapangan, masyarakat tampaknya mulai terbiasa dengan kemudahankemudahan yang terdapat dalam smartphone, terlebih setelah mereka mengetahui cara berdagang online melalui pelaksanaan Siklus IV. Kotler \& Amstrong (1997) menyebutkan bahwa proses penjualan lebih praktis menggunakan mobilephone karena rekam jejak penjualanpun tersimpan di dalam aplikasi.

\section{PENUTUP}

\section{Kesimpulan}

Penelitian ini telah menyajikan informasi terkait optimalisasi pemberdayaan masyarakat melalui penggunaan smartphone untuk pengembangan potensi masyarakat di Desa Cikoneng, Sumedang. Penelitian ini dipandang penting untuk dilakukan karena sampai saat ini belum ada penelitian secara ekstensif terkait pemanfaatan smarthone untuk dunia usaha (UKM) yang ada di wilayah masyarakat daerah. Penelitian ini mungkin saja menginisiasi pengembangan penggunaan smartphone untuk mensupport kegiatan perekonomian di Indoneisa, khususnya di daerah. Penelitian juga telah menemukan bahwa masyarakat sudah bisa mengoperasikan smartphone untuk keperluan berdagang atau transaksi jual beli online.

\section{Saran}

Hasil penelitian menyarankan bahwa diperlukan rencana kerja tindak lanjut untuk mengetahui efektifitas pemberdayaan masyarakat melalui penggunaan smartphone dalam mengembangkan potensi usahanya. Diperlukan juga tindak lanjut pemberdayaan jangka panjang terkait upaya masyarakat dalam memperoleh bantuan dana atau modal usaha dari dinas pemerintahan.

\section{DAFTAR PUSTAKA}

Bull, G \& Thompson, A. (2004). 'Establishing Framework for Digital Images in the School Curriculum', Leading and Learning with Technology (31) 8, pp. 14-17.

Fridayanti., Sururie, W.W., Aziz, R., Uriawan, W., Zulqiah., \& Mardiansyah, Y. 2019. Model KKN Sisdamas UIN Sunan Gunung Djati Bandung: Tantangan dan Peluang Pelaksanaan. Alkhidmat: Jurnal Ilmiah Pengabdian kepada Masyarakat, Vol2(1), 2327.

Idris, I.K 2018. Government Social Media in Indonesia: Just Another Information Dissemination Tool. Malaysian Journal of Communication, 34(4), 338-356.

Ife, J. 1995. Community Development: Creating Community Alternatives, Vision, Analysis and Practice. Australia: Longman.

Kemenko PMK. 2019. 16.4 Juta Pengguna Medsos Asal Jawa Barat. Jabarprov.go.id

Kee, CL \& Samsudin, Z. (2014). 'Mobile Devices: Toys or Learning Tools for the 21st Century Teenagers?', TOJET: The Turkish Online Journal of Educational Technology (13) 3, pp. 107-122.

Khaloufi, Az-eddine \& Laabidi, Hicham. 2017. An Examination of the Impact of Computer Skills on the Effective Use of ICT in the Classroom. Indonesian Journal of EFL and Linguistics, 2(1), 2017 
Kotler, P. \& Armstrong, G. 1997. Prinsip-Prinsip Pemasaran. Jakarta: Penerbit Erlangga.

Lenhart, A. 2015. Teens, Social Media \& Technology. Newyork: Pew Research Center.

Markett, C, Sanchez, IA, Weber, S \& Tangey, B. 2006. 'Using Short Message Service to Encourage Interactivity in the Classroom', Computers and Education, pp. 280-293

Netting, R.M., Kettner dan McMurtry. 1993. Smallholders, Householders: Farm Families and the Ecology of Intensive, Sustainable Agriculture. Stanford: Stanford University Press.

Pegrum, M., Oakley, G., \& Faulker, R. 2013. Schools going mobile: A study of the adoption of mobile handheld technologies in western australian independent schools. Australasian Journal of Educational Technology, 29(1), 661.

Pramuditya, D. 2014. Pemanfaatan Teknologi Informasi dan Komunikasi di Tingkat Pemerintahan Desa. Jurnal Penelitian Komunikasi, Vol17(2), 129-140.

Prensky, M. 2001. 'Digital Natives, Digital Immigrants', On The Horizon (9) 5.

Ridwan, A.M., Hakim, R.N., \& Firmansyah, E. 2018. Penerapan dan Tantangan dalam Penerapan Teknologi Informasi dan Komunikasi di Tingkat Pemerintahan Desa. Tesis. Sumedang: STMIK Sumedang.

Rogers, R., Weltevrede, E., Niederer, S., \& Borra, E. 2012. National Web Studies: Mapping Iran Online. Amsterdam: Amsterdam University Press.

Smythe, S \& Neufeld, P. 2010. 'Podcast Time. Negotiating Digital Literacies and Communities of Learning in a Middle Years ELL Classroom ', Journal of Adolescent \& Adult Literacy (53) 6, pp. 488-496.

Sururie, Ramdani Wahyu, Rohmanur Aziz, Fridayanti, Yadi Mardiansyah, Wisnu Uriawan, and Zulqiyah. 2016. Paradigma dan Siklus KKN Sisdamas. Bandung: Lembaga Penelitian dan Pengabdian kepada Masyaralat (LP2M) UIN Sunan Gunung Djati.

Twelvetrees, A. 1991. Social Planning Approaches to Community Work. In: Community Work. Practical Social Work. London: Palgrave.

Zeng, R \& Luyegu, E. (2011). 'Mobile Learning in
Higher Education', in Informed Design of Educational Technologies in Higher Education: Enhanced Learning and Teaching, Idea Group Inc (IGI), Herhsey, Philadelphia.

Yudhiantara, R.A., \& Saehu, A. 2017. MobileAssisted Language Learning (MALL) in Indonesian Islamic Higher Education. Indonesian Journal of English Language Teaching and Applied Linguistics. Vol.2(1). 21-31. 